\title{
The impact of climate change on water resources in Bosnia and Herzegovina
}

Erina Dakić, M.Eng.C.E. erinadakic@gmail.com

\begin{abstract}
Continuously raising awareness of the issue of climate change helps to better understand it, but there is very little or no implementation of activities to mitigate the effects in practice. Therefore, it is important to collect data, perform analyses and studies in order to improve the existing situation. The paper provides an overview of the current condition caused by climate change with a focus on water resources in Bosnia and Herzegovina, possible consequences in the future and measures recommended to be applied as a means to minimize the negative effects.
\end{abstract}

Key words: climate change, precipitation, impacts, water resources, consequences

\section{Utjecaj klimatskih promjena na vodne resurse u Bosni i Hercegovini}

Sažetak: Kontinuirano podizanje svijesti o problematici klimatskih promjena doprinosi boljem razumijevanju iste, ali nailazi na vrlo malu ili nikakvu primjenu aktivnosti za reduciranje posljedica u praksi. Stoga je važno prikupljati podatke, vršiti analize i istraživanja u cilju poboljšanja postojeće situacije. $U$ radu se daje pregled dosadašnjeg stanja uzrokovanog klimatskim promjenama $s$ fokusom na vodne resurse u Bosni i Hercegovini, moguće posljedice u budućnosti i mjere koje se preporučuje primijeniti kao sredstvo za minimiziranje negativnih posljedica.

Ključne riječi: klimatske promjene, padavine, utjecaji, vodni resursi, posljedice 
Dakić, E.

The impact of climate change on water resorces in Bosnia and Herzegovina

\section{INTRODUCTION}

Water has always had a central place in human life. In addition to being essential to any form of life as we know it today, this is also supported by the knowledge that people have been striving to use water resources in the most purposeful and rational way possible from ancient times. Thus, the first civilizations in the valleys of the rivers Nile, Tigris, Euphrates used water for irrigation and food production purposes. Drinking water reserves are not inexhaustible, therefore as a society and as individuals we have the task to use it conscientiously and responsibly.

Awareness of water resources has rapidly increased with an equally sharp increase in population during the twentieth century, where, according to UN estimates, the population of planet Earth increased from 1.65 billion to 6 billion over a period of a hundred years. The population is expected to be 9 billion by 2050, but the quantities of drinking water will remain approximately the same. The management of water resources is an exceptionally important task, considering their limitations. Water control and management are based on input values, of which climate data is a significant type. They contribute to a better understanding of the interaction of various components of the climate system including the hydrosphere, atmosphere, biosphere, and cryosphere. [11]

The causes of climate change result from the interaction of natural and anthropogenic factors. Greenhouse gases that intensify the greenhouse effect and contribute to the recent trend of global warming are considered to be the most significant factor. The current average temperature at a global level is higher by $0.85{ }^{\circ} \mathrm{C}$ than at the end of the $19^{\text {th }}$ century, and $2{ }^{\circ} \mathrm{C}$ compared to pre-industrial times. Today, forest fires, increased flood risks, frequent storms, and deterioration of air quality also occur as adverse effects. These changes should be constantly monitored in order to be able to predict changes in water resources and their interdependence. [11]

\section{CLIMATE CHANGE}

Climate change is a change in the properties and distribution of climate factors over a period of decades or longer. The UNFCCC defines it as a climate variability directly and indirectly affected by human activity, that alters the composition of the atmosphere, and is observed over comparable periods of time. The causes of climate change result from the interaction between water, atmosphere and soil, therefore a human, natural or combined action can result in a change in any of these systems. One of the main causes is the change of greenhouse gases in the atmosphere. [8]

\subsection{Greenhouse effect}

The greenhouse effect affects the appearance of the Earth as we know it. Greenhouse gases form a thermal blanket around the Earth and form a climate that is conducive to life. Without them, air temperatures would be significantly lower, presumably even up to $30{ }^{\circ} \mathrm{C}$. The greenhouse effect is a process in which the Earth's surface is warmed by the Sun's heat, $70 \%$ of the Sun's radiation is reflected, and greenhouse gases absorb it and thus warm the atmosphere too. (Figure 1). This means that if the concentration of greenhouse gases (carbon dioxide, methane, water vapor, nitrous oxide) increases, air temperatures will also increase. [6] 
Dakić, E.

The impact of climate change on water resorces in Bosnia and Herzegovina

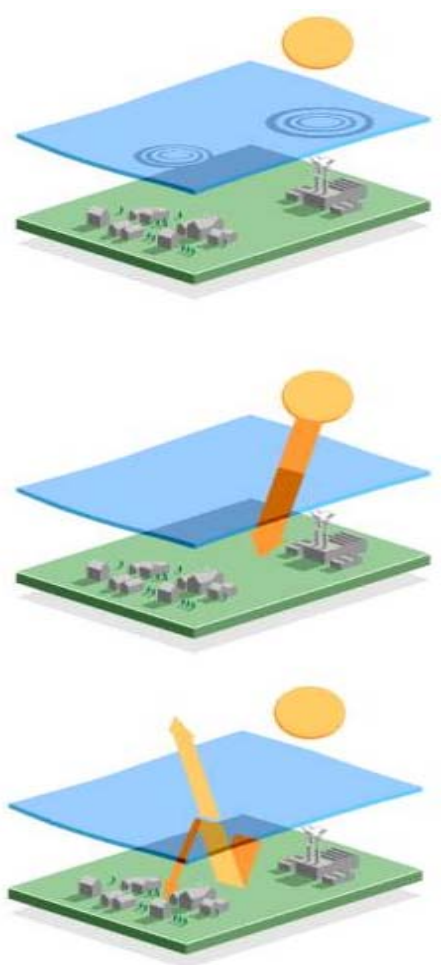

Figure 1. Greenhouse effect [6]

The amount of $\mathrm{CO} \square$ and other greenhouse gases in the atmosphere has been increasing for years. The reason for this is the rapid development of industry, burning of fossil fuels, logging, increased cattle breeding (production of large amounts of methane during food digestion), the use of fertilizers containing nitrogen, etc. [8] The obvious consequences are an increase in average annual temperature and changes in precipitation regime.

\subsection{Climate change in Europe}

Depending on the regions, climate change will have different impacts on Europe's waters. The change in air temperature affects the condition of thermal masses, movement of water and the distribution of precipitation in time and space. Differences in the availability of water resources between northern and southern Europe are expected to increase. Annual precipitation indicates an increase in humidity and flood risk in northern and continental Europe (increase in humidity of up to $10 \%-40 \%$ during the last century), while in southern Europe there will be an increase in drought periods and decrease in soil moisture (decrease in humidity of up to $20 \%$ during the last century). Annual river flow has increased in eastern Europe while it has decreased in southern Europe. Aquifer recharge will be reduced, lowering of water table will occur, and it will be particularly pronounced in Italy, France, Belgium and Spain. These consequences will bypass the aquifers in Switzerland and Great Britain. [3]

On the other hand, higher temperatures reduce the occurrence of snowfall and cause snow from mountain tops to melt. This combination will result in higher water levels in the Rhine, Danube, Rhone and Po rivers, whose sources are in mountain massifs and which are of exceptionally high importance for the development of the European economy. Changes at 
Dakić, E.

The impact of climate change on water resorces in Bosnia and Herzegovina

the highest points of flows will result from reduced snowfall, reduced glaciers and aquifer recharge, there will be less water in the summer to balance low flows. [4]

It is precisely in the summer months that the problem of high water demand will occur, especially in the Mediterranean areas due to irrigation, and will cause problems in agronomy and agriculture. Rising sea levels can lead to salinization of coastal and island water resources and thus contribute to the shortage of drinking water. Changes in average water availability caused by the effects of altered climatic factors will be relatively small in most river basins over the next 30 years. However, scenarios in which northern and eastern Europe will experience an increase in average annual water inflows are expected in the long run, and in contrast, southern Europe, especially the Mediterranean region already facing water stress, will face reduced availability of water resources. [2]

\section{WATER RESOURCES MANAGEMENT}

Water resources management is an environmentally sensitive activity the primary goal of which is to meet the needs of consumers guided by the principles of rational use of water resources and environmental protection. Water management is related to the activities focused on water use, protection against harmful effects of water and protection of water from harmful effects and pollution. These activities are performed by the interaction of experts from different spheres of science, technique and technology. For this reason, the Integrated Water Resources Management (IWRM) started being discussed at the International Conference in Dublin in 1992. IWRM is based on sustainable water resources management with the aim of protecting the environment and economic resources. In addition to surface water, it includes groundwater and water lost by evapotranspiration as water resources management components. It involves water management at the level of the river basin as a spatial unit, where all the water will reach a certain point in the watercourse. (Figure 2). Such an approach implies an integrated and successful way of managing water resources and a measure to reduce water conflicts. [11]

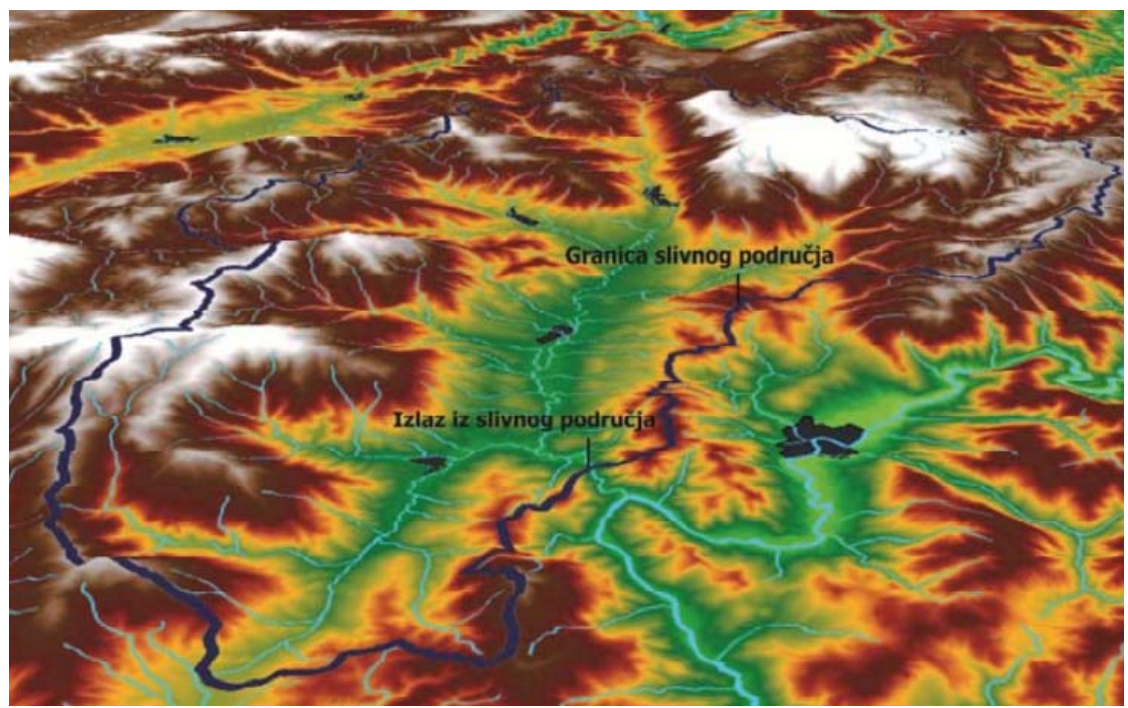

Figure 2. Catchment area [11]

An integrated approach to water resources management involves a combination of natural and social systems, or a combination of water resources characteristics with anthropogenic factors. Different disciplines are integrated: economics, law, mathematics, 
Dakić, E.

The impact of climate change on water resorces in Bosnia and Herzegovina

ecology, technology and others, which make it possible to solve problems through joint action.

IWRM covers the management of land, or space and ecosystems in the catchment area. The laws on impact on the downstream system, which suffers due to excessive use and high pollution on the upstream system, are respected. Groundwater is observed together with surface water, because external actions and pollution equally affect groundwater resources too. From the aspect of human factor integration, it is crucial to involve and connect all stakeholders for the purpose of optimizing and balancing water resources management as much as possible. This includes integration of water resources with the national sectoral policy, especially with the sectors directly affecting water resources and vice versa (agriculture, forestry, etc.). [11]

For a successful water resources management, it is important to adhere to the principles of economically efficient and equitable water use and environmental sustainability. To implement IWRM, it is necessary to understand and define several steps that will accompany the water management process. (Figure 3)

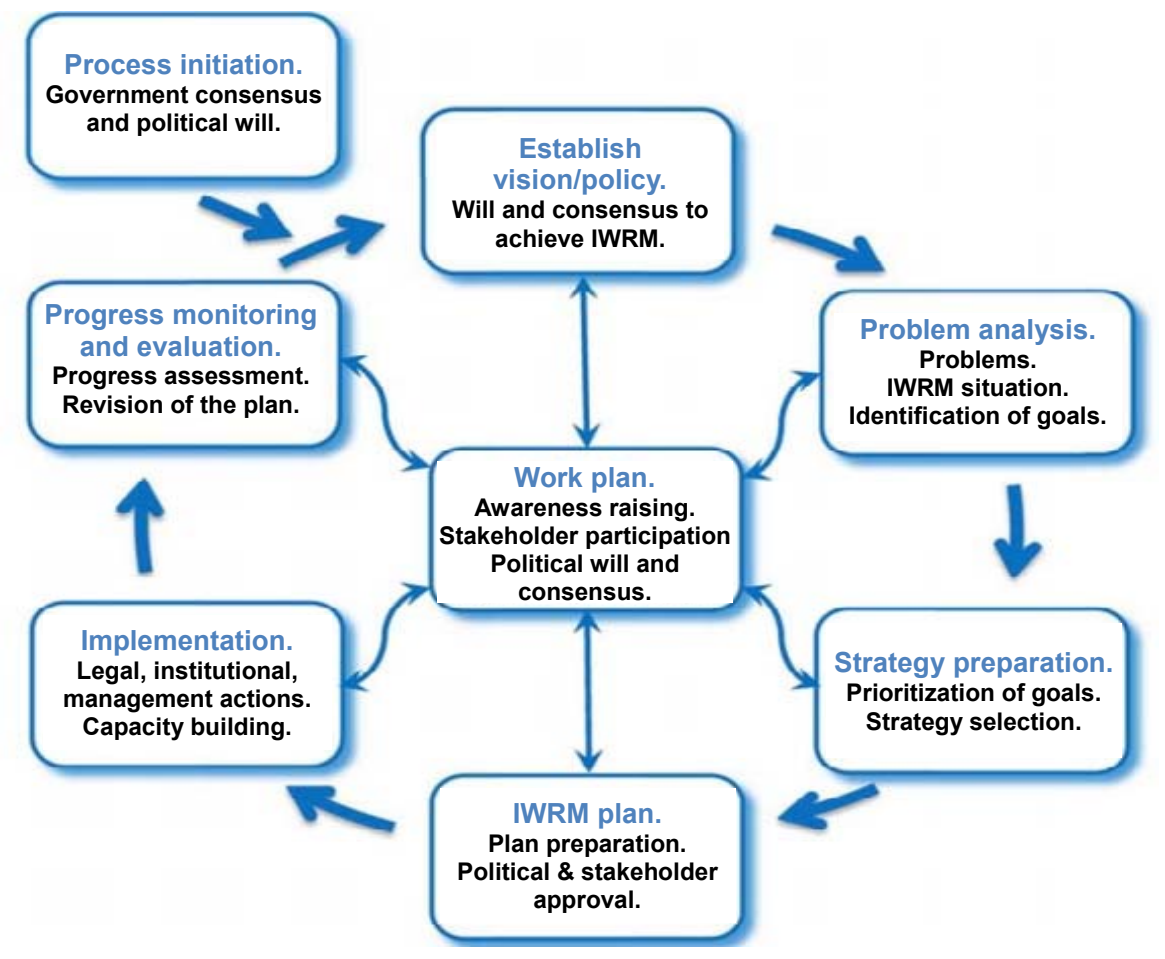

Figure 3. IWRM implementation steps [11]

Integrated water resources management is aimed at providing water supply to the population, providing sufficient quantities of technological water and water for economic purposes, improving the quality of drinking water and preserving water resources to the maximum extent.

\section{ANALYSIS OF THE SITUATION IN BOSNIA AND HERZEGOVINA}

The climate of Bosnia and Herzegovina varies from a temperate continental climate in the Pannonia lowlands, to an alpine climate in the mountains to a Mediterranean climate in the south of the country. The average annual temperature in coastal areas is between 12 and 17 
Dakić, E.

The impact of climate change on water resorces in Bosnia and Herzegovina

${ }^{\circ} \mathrm{C}$, in lowland areas between 10 and $12{ }^{\circ} \mathrm{C}$, and in areas above $400 \mathrm{~m}$, the temperature is below $10^{\circ} \mathrm{C}$. Annual precipitation ranges from $800 \mathrm{~mm}$ to $2000 \mathrm{~mm}$, from the north inland. [7]

Studies on temperature changes from the period 1961-2010 show an increase in temperatures by $0.4{ }^{\circ} \mathrm{C}$ to $1{ }^{\circ} \mathrm{C}$ on an annual basis in all parts of the country. The largest increase in average temperature in the summer months was registered in Herzegovina and central areas (Mostar $-1.20{ }^{\circ} \mathrm{C}$ and Sarajevo $-0.80{ }^{\circ} \mathrm{C}$ ), and during spring and winter in the northern central areas (Banja Luka $-0.70^{\circ} \mathrm{C}$ ). [10]

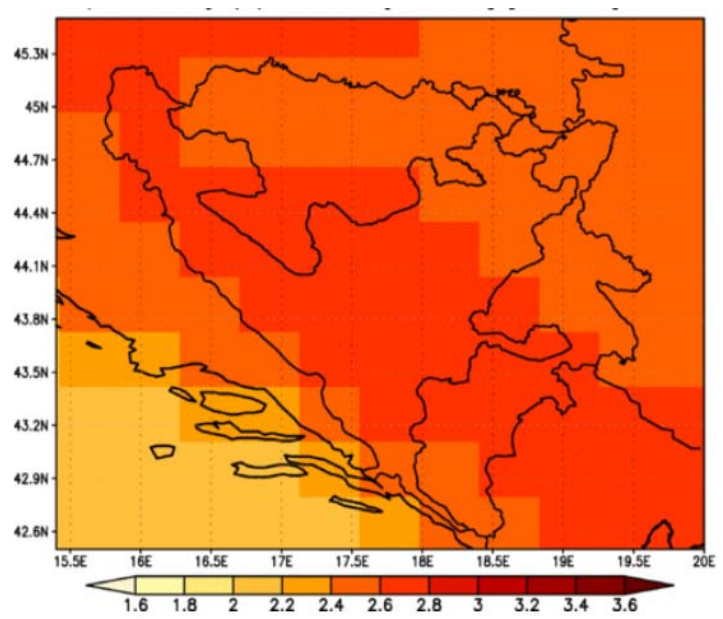

Figure 4. Forecast of annual temperature changes in Bosnia and Herzegovina for the period 2071-2100 in relation to 1961-1990 [10]

As a consequence of these changes, two extreme events have occurred in Bosnia and Herzegovina to date: the drought in 2012 and the flood in 2014. [4]

In the period from 1981, a decrease in days with rainfall during the year was registered, and a trend was observed of increased rapid transition from extremely hot or cold periods to periods of intense rainfall, increased droughts and maximum wind speeds. In the period 2071-2100, an extreme rise in temperatures of up to $4 \%$ on an annual basis and the maximum deficit of precipitation of as much as $50 \%$ in the summer months are expected in relation to the reference period 1961-1990. (Figure 5) [9]

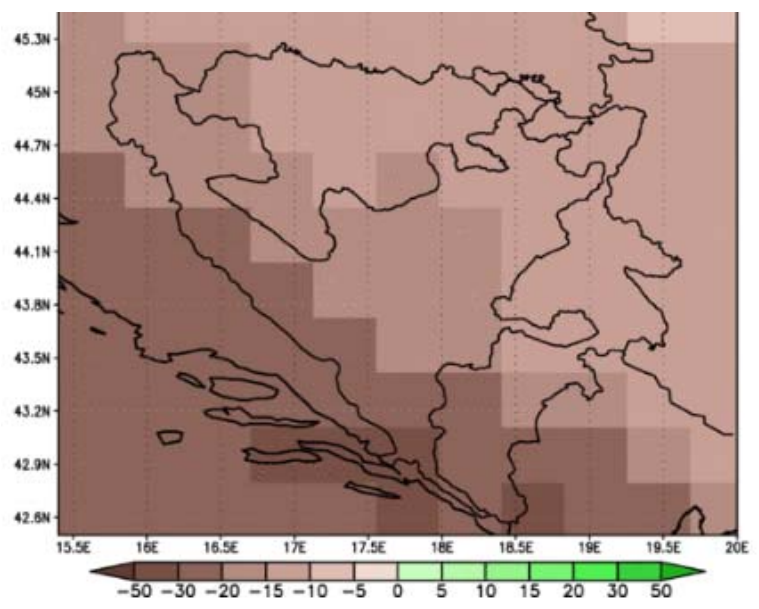

Figure 5. Forecast of precipitation changes for the period 2071-2100 in relation to 1961-1990 [10] 
Dakić, E.

The impact of climate change on water resorces in Bosnia and Herzegovina

\section{EFFECTS OF CLIMATE CHANGE ON WATER RESOURCES IN BOSNIA AND HERZEGOVINA}

The water resources of Bosnia and Herzegovina consist of two main basins: the Black Sea basin $\left(38,719 \mathrm{~km}^{2}\right)$ and the Adriatic Sea basin $\left(12,410 \mathrm{~km}^{2}\right)$. The average outflow of surface water is $1155 \mathrm{~m}^{3} / \mathrm{s}$, or $57 \%$ of the total volume of precipitation. The outflow from the Danube catchment area (76\% of the BiH territory) is $22.77 \mathrm{~km}^{3}$ annually or $62.5 \%$ of the total volume of water, while the remaining $13.66 \mathrm{~km}^{3} /$ year flows to the Adriatic Sea. (Figure 6) [11]

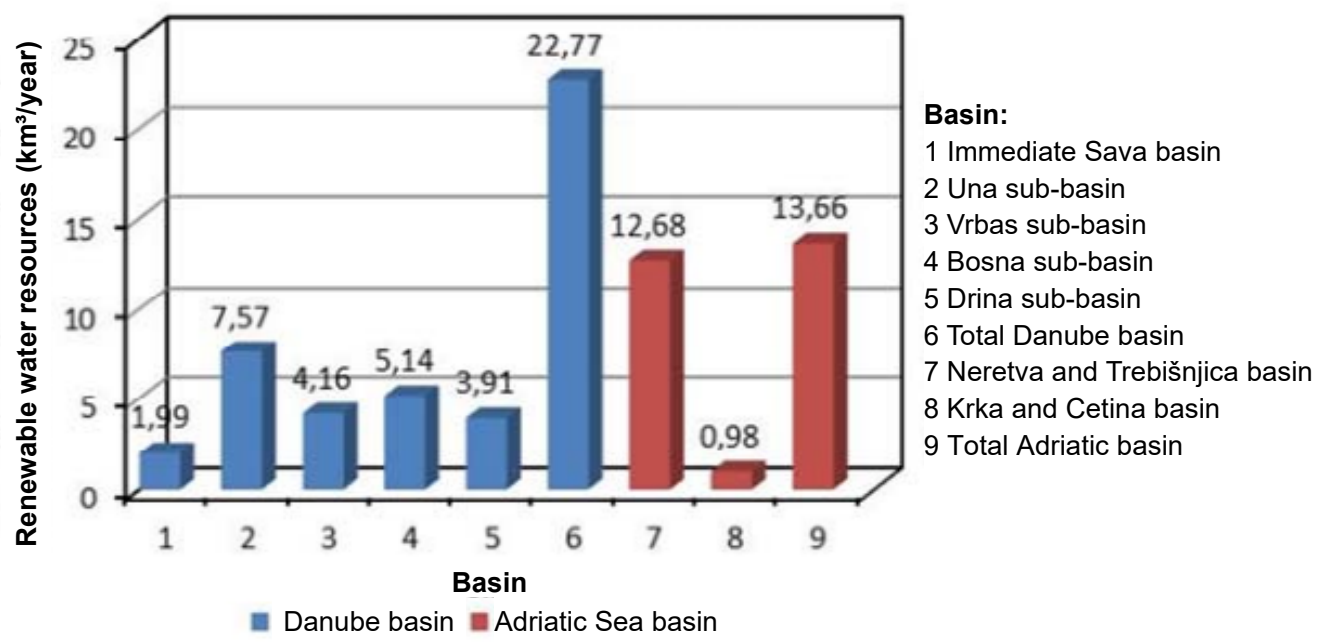

Figure 6. Total renewable water resources [11]

The largest renewable water resources per capita are available in the Neretva and Trebišnjica catchment areas, around 29,060 m³/capita/year. (Figure 7)

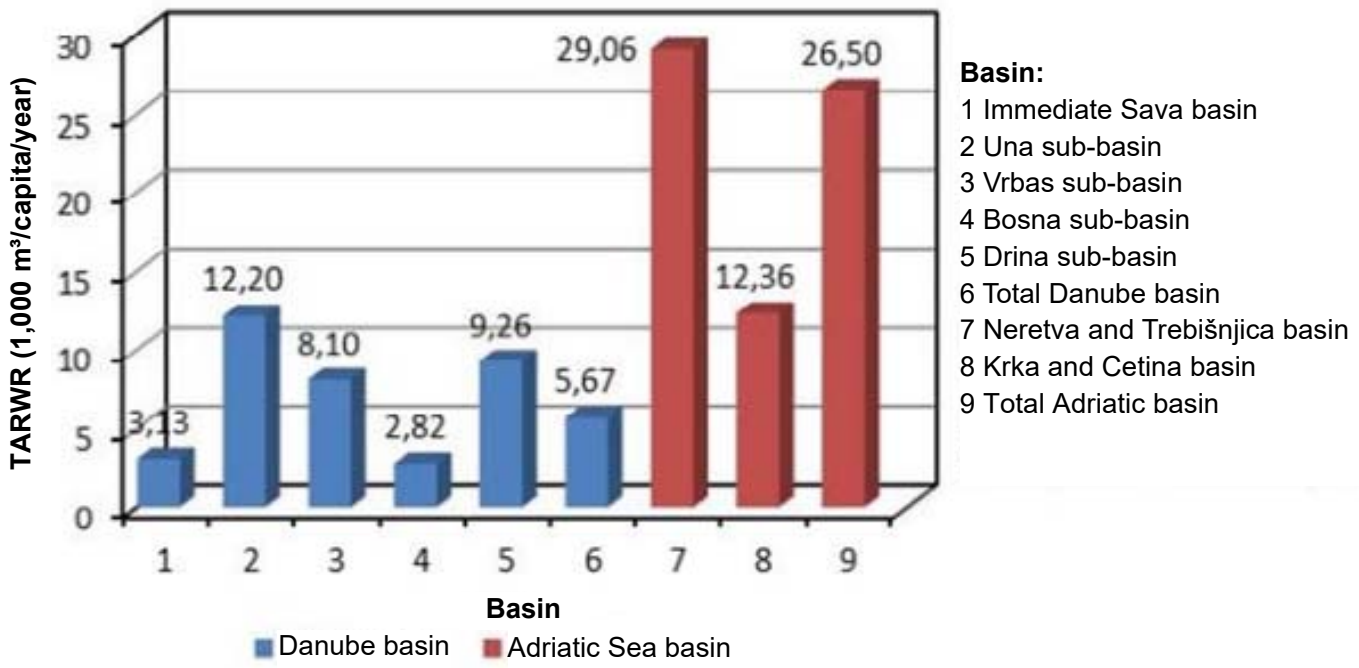

Figure 7. Total renewable resources per capita [11]

The basin of the Bosna River with the available water volume of $2820 \mathrm{~m}^{3} / \mathrm{capita} / \mathrm{year}$ is at highest risk. It covers $20.4 \%$ of the territory of Bosnia and Herzegovina, is inhabited by $40.2 \%$ of the population, and its outflow comprises only $14.1 \%$ of available water resources. 
Dakić, E.

The impact of climate change on water resorces in Bosnia and Herzegovina

In dry periods, these volumes decrease to less than $60 \%$ of the average volumes. In 2011 , the total volume of water abstracted and taken over in Bosnia and Herzegovina was $329,954,000 \mathrm{~m}^{3}$, which is $3 \%$ less than in 2010. [1]

Despite the fact that Bosnia and Herzegovina has significant water resources, it is estimated that as much as $57 \%$ of them flow away unused, while the quality of drinking water is deteriorating. It is assumed that temperature and precipitation changes have a negative impact of on water resources. Water systems are directly exposed to climatic factors, so an increase in temperature and decrease in precipitation in the summer months will prolong dry periods and lead to droughts (the limestone karst areas will be the most exposed), while, in contrast, during the autumn, there will be another extreme - floods. The recurrence period of these conditions is estimated to be 5 to 10 years. Climate change will also lead to the instability of river water levels and lowering of water table, which will significantly reduce electricity generation, capacity of drinking water supply and will affect tourism. The management of hydrological data is limited and makes it impossible to complete the picture of change in the condition of water resources in Bosnia and Herzegovina. [9]

\section{CONCLUSION}

Climate instability is present in all seasons, and the consequences of climate change are evident all over the world, and so in Bosnia and Herzegovina too. We witness negative consequences and extreme events in all sectors. Bosnia and Herzegovina is a signatory to different international treaties and agreements and as such is encouraged to protect resources, reduce gas emissions and protect the environment. Despite this, there is a lack of state and regional cooperation, research and analyses of impacts do not follow the trends in Europe, and flood control infrastructure is degraded and destroyed by war and post-war events. There are no specific models related to the behavior of aquatic and ecosystems affected by climate change. [5]

A key element of climate change is the circulation of water on the Earth. Climate change has an effect on increasing levels of water vapor in the atmosphere and changing precipitation regime, which can lead to heavy rains in some areas that are already exposed to high humidity, and in others to water shortage. The shortage of drinking water will affect the global economy, and key problems are also the shortage of water required for the operation of different plants, water quality deteriorated by floods and droughts, different pollutions, salinization of coastal areas and increasing water temperatures. Snow and ice cover decrease and their duration is shortened. These changes also affect the quality of water and aquatic habitats. The consequences of climate change are evident both on a global and local level, and it is possible to predict that even more drastic scenarios will occur in the future. [8]

Adaptation measures are focused on water use in the sectors using large amounts of water. The best way to apply the measures would be timely preparation and response to the causes. Bosnia and Herzegovina should target funding on sustainable management of water resources and their rational use, as well as the use of treated wastewater in combination with rainwater for irrigation purposes and reduction of greenhouse gas emissions. In order to further preserve water resources and the water sector in Bosnia and Herzegovina, it is necessary to develop activities aimed at harmonization with the relevant EU legislation. One of the proposed measures to address the deficiencies is the development of a hydrological information system (HIS). HIS is a system for collecting, analyzing and storing hydrological data that can be used at any time. An analysis of water systems and regimes in Bosnia and Herzegovina would contribute to research on the impact of climate change on water resources in Bosnia and Herzegovina. Also, it would be necessary to render operable and 
Dakić, E.

The impact of climate change on water resorces in Bosnia and Herzegovina

invest in water management facilities in accordance with IWRM (Integrated Water Resource Management) principles. Water demand management is another aspect of conserving water resources in $\mathrm{BiH}$. The primary goal of implementing this measure would be to reduce losses and excessive use of water and to adapt water resources to climate change. One of the possible solutions to the water management problem in this context is reservoirs. They are an ideal way to optimize the use of water resources and make their use possible in any season of the year. [7]

The level of awareness of climate change and of the consequences it has on life on Earth is still not at a satisfactory level. It is a fact that the impact cannot disappear, but all the necessary measures should be taken to be able to control it and to minimize the negative consequences.

\section{REFERENCES}

1. Agency for Statistics of Bosnia and Herzegovina, link

(http://www.bhas.ba/saopstenja/2012/VOD2V_2011_001_01_BA_02\%20hr.pdf), accessed: 25.4.2020

2. Beraković, M.; Beraković, B. 2011. Klimatske promjene i voda. In: Biondić, D.; Holjević, D.; Tropan, Lj., Hrvatske vode pred izazovom klimatskih promjena, Opatija: Hrvatske vode, pp.79-87

3. Climate impacts on water resources, European Environment Agency, link (https://www.eea.europa.eu/archived/archived-content-water-topic/water-resources/climateimpacts-on-water-resources), accessed: 23.4.2020

4. Drugi nacionalni izvještaj (SNC) o klimatskim promjenama (Second National Communication on Climate Change), Council of Ministers of Bosnia and Herzegovina, 2013

5. Ministry of Foreign Trade and Economic Relations of Bosnia and Herzegovina, link (http://www.mvteo.gov.ba/Content/Read/vodni-resursi), accessed: 26.4.2020

6. Ministry of Environment and Nature Protection, link (http://klima.mzoip.hr/default.aspx?id=4), accessed: 2.5 .2020

7. Prvi nacionalni izvještaj o klimatskim promjenama (Initial National Communication on Climate Change), Council of Ministers of Bosnia and Herzegovina, 2009

8. Singh, V.; Mishra, A.; Khedun, P.; Chowdhary, H.: Climate change and its impact on water resources, link

(https://www.researchgate.net/publication/314210788_Climate_Change_and_Its_Impact_on Water_Resources), accessed: 21.4.2020

9. Strategija prilagođavanja na klimatske promjene i niskoemisionog razvoja za Bosnu i Hercegovinu (Climate Change Adaptation and Low Emission Development Strategy for Bosnia and Herzegovina), Council of Ministers of Bosnia and Herzegovina, 2013

10. UNFCCC BiH, link (http://www.unfccc.ba/site/pages/ranjivost_prilagodjavanje.php), accessed: 25.4 .2020

11. Vučijak, B.; Silajdžić, I.; Kurtagić, S.; Ćerić, A.: Voda za život: Osnove integralnog upravljanja vodnim resursima (Water for Life: Fundamentals of Integrated Water Resources Management). Bosnia and Herzegovina, Sarajevo, 2011, link (https://www.undp.org/content/dam/unct/bih/PDFs/OsnovelWRMbs.pdf), accessed: 24.4.2020 